\title{
Severino Ngoenha: política e liberdade no Moçambique contemporâneo
}

\author{
Eduardo Felisberto Buanaíssa ${ }^{1}$ \\ Marçal de Menezes Paredes ${ }^{2}$
}

Severino Elias Ngoenha tem sido considerado pela academia moçambicana como o mais influente filósofo do país. Esta apreciação marca, por si só, uma boa chave de leitura para a interpretação do referido filósofo. Se, por um lado, Ngoenha jamais descurou do diálogo com a tradição da filosofia ocidental, nem tampouco deixou de tratar da afirmação positiva da filosofia africana, será no solo de seu país - Moçambique - que suas reflexões terão maior pujança e melhor ventura. Sua obra pode ser considerada como uma indagação filosófica sobre a liberdade a partir das contradições próprias da história contemporânea de Moçambique. Desde suas primeiras obras Por uma Dimensão Moçambicana da Consciência Histórica (1992) e Filosofia Africana: das independências as liberdades (1993), Ngoenha reflete sobre a adiada liberdade, prometida pela Independência (1975) e entretanto abruptamente limitada pela Guerra Civil Moçambicana (1976-1992) e pelo modus operandi da administração política da época.. A

\footnotetext{
${ }^{1}$ Professor de Filosofia da Universidade Pedagógica de Moçambique e Doutorando em Educação na Universidade de Giessen, Alemanha. E-mail: ja.edu@hotmail.com

${ }^{2}$ Professor-Adjunto da Escola de Humanidades e do Pós-Graduação em História da PUCRS. Doutor em História pela Universidade de Coimbra e Pesquisador-Associado do Centro de Estudos Interdisciplinares do século XX (CEIS2o), da Universidade de Coimbra, Portugal. E-mail: marcal.paredes@pucrs.br
} 
violência que os tempos a guerra levaram ao paroxismo desumano, e transmuta-se no dia-a-dia da relação entre sociedade civil e Estado, novamente limitando o exercício da liberdade a partir dos efeitos danosos das negociações duvidosas da abertura da econômia nacional ao FMI e ao capitalismo globalizado. Recentemente, Ngoenha torna a problematizar o país em Resistir a Abadon (2018). Sua mirada reflexiva torna a encarar a violência e a convidar para uma ampliação da liberdade.

\section{Trajetória Intelectual}

Moçambique é um país marcado pela diversidade étnica (mais de 20 etnias) dispersa em grande extensão territorial (mais de 800 mil quilômetros quadrados) e grande variabilidade de povos e religiões, bem como por grandes migrações. O sobrenome Ngoenha é oriundo da região central do país, província de Sofala, da etnia Ndau (marcada, historicamente, pela memória de resistências no período colonial). Em entrevista realizada por Helena Bomeny, Guilherme Mussane e Arbel Griner, em 2011, em Salvador da Bahia ${ }^{3}$, Severino mostra que, mais do que ser Ngoenha (com uma geografia etnicamente localizada), é um pensador moçambicano e cidadão do mundo. Nascido em Maputo, em 1962, tendo os pais oriundos da Província de Gaza, Severino Ngoenha, como se verá, terá um percurso de formação intelectual e acadêmica muito instigante. Será desta trajetória que se descobrirá como filósofo, como africano e, principalmente, como pensador moçambicano.

Inicia sua formação na educação básica na Escola oficial portuguesa, criada especialmente para portugueses de origem ou assimilados ${ }^{4}$. Depois da independência em 1975, já concluído o

\footnotetext{
${ }^{3}$ Entrevista concedida por Helena Bomeny, Guilherme Mussane e Arbel Griner, no âmbito do Projecto Cientistas Sociais de Países de Língua Portuguesa: histórias de vida, 10 de Agosto de 2011.

${ }^{4}$ Umas das características mais marcantes do colonialismo português foi a política de assimilação seletiva que, entre outros elementos, fazia diferenciação jurídico-política da população colonial em
} 
Liceu, inicia estudos em Biologia e Química na Universidade Eduardo Mondlane, formação que não terminará por influência da sua vida religiosa. Sua devoção ao cristianismo fê-lo decidir pelos estudos teológicos, com particular interesse pela Teologia da Libertação em voga na América Latina através dos Dussel, Leonardo Boff e outros. Entra então para o Seminário Pio X em Maputo, permanecendo dois anos numa formação sacerdotal em teologiafilosofia.

Durante os dois anos de estudos no Pio X, a Teologia da Libertação o fascina ao ponto de nela ver a possibilidade de alargar a independência na altura acabada de alcançar-se do ponto de vista formal-político. Severino almejava ajudar a construir uma sociedade mais justa. Em suas palavras: "porque as representações sociopolíticas, as utopias sociais que se apresentavam não correspondiam àquela imagem que eu queria construir da sociedade. E quando eu descobri a Teologia da Libertação, pareciame uma resposta a esse tipo de desafio" (NGOENHA, 2013 p.9).

Depois dos anos no PIO X, em 1984 Ngoenha ganha uma bolsa de estudos para continuar com os seus estudos de graduação em Teologia e Filosofia na Universidade Gregoriana de Roma. Na Itália partilha a formação com colegas vindos de várias partes do mundo, desde Brasil, Nigeria, Vietnam, Uganda, Síria, Turquia, entre outros. É interessante notar que "foi paradoxalmente na capital da cristandade que aprendeu a ser africano" (BUANAISSA, 2016, p.342).

Em Roma, em conversas e leituras com colegas oriundos de espaços de um pensamento filosófico africano, de natureza bastante crítica, o que na altura não existia em Moçambique, Ngoenha descobre o seu interesse pelo estudo da filosofia africana, e como as independências ainda estava no limiar da construção das liberdades, ele adscreve-se a uma a filosofia da libertação. A sua contribuição 
não era no sentido da etnofilosofia de Placid Tempels, mas a uma abordagem mais hermenêutica, produto de uma tradição iniciada pelo filósofo camaronês Fabian Eboussi-Boulaga. Foi essa filosofia que o devolve a Moçambique em termos académicos. Como ele afirmou: "e posso dizer que eu fui a pessoa que introduziu a filosofia africana em Moçambique. Aliás, eu fiz os programas, todos os programas de filosofia em Moçambique, de filosofia, na época pósmarxista”. Será nesse contexto que se abrirá espaço para a reflexão em torno da filosofia africana. Severino Ngoenha tem protagonismo nesse momento: "e um dos temas que introduzi (...) é a filosofia africana. Então, nesse sentido, Roma permite-me de descobrir um africano” (NGOENHA, 20113, p.13).

Concluídos seus estudos em Roma em 1988, Ngoenha parte para Paris para finalizar a tese de Doutorado sobre Voltaire. Pouco depois desloca-se a Lousane, na Suíça, onde é aprovado em concurso como professor e pesquisador. Depois de algum tempo morando e trabalhando na Suíça, já com uma família constituída (esposa e dois filhos suíços) Ngoenha ganha a nacionalidade daquele país, o que segundo ele - a "única" vantagem desse passaporte - facilita as suas deslocações além fronteiras, para participar da vitalidade do mundo das ciências humanas e sociais.

Apesar de ter ido e encontrando um lugar confortável na Suíça, de se ter doutorado em Filosofia da História, Ngoenha não se desligou de África (através da Filosofia Africana) e de Moçambique (por intermédio de visitas regulares a familiares e a trabalho). Nos anos 1995, na qualidade de Professor convidado, é chamado a dar aulas na extinta Unidade de Formação e Investigação em Ciências Sociais (UFICS), da Universidade Eduardo Mondlane (um instituto que hoje poderíamos comparar a uma faculdade de ciências sociais e humanas). Naquele instituto, que também contava com as visitas do sociólogo moçambicano Elisio Macamo, as suas aulas estavam voltadas a introdução do Pensamento Africano. Com Ngoenha, esta disciplina foi mesmo introduzida no currículo institucional. Essa contribuição era dada simultaneamente - e com mais vigor, 
incluindo com um programa multidisciplinar - a Universidade Pedagógica, que em 2010 acolheu o seu regresso a Moçambique de forma definitiva.

Os esforços Severinianos de introduzir filosofia e de militar pelas ciências sociais em Moçambique, carregavam-se de um posicionamento crítico às dinâmicas de fazer ciência e desenvolvimento com as vestes das bandeiras ocidentais. Era mais ou menos uma espécie de cópia do caminho europeu de desenvolvimento. Afinal, conforme ele, quando a racionalidade moderna negou Deus em troca do desenvolvimento tecnicoindustrial. Segundo Ngoenha, o Ocidente havia eliminado Deus, contudo, para África, o Ocidente havia se tornado um novo "outro" Deus. Era esse Deus que África, através das ciências sociais, queria eliminar, para por intermédio de instituições como o CODESRIA de Samir Amin, criar novas formas de desenvolvimento, e por isso, caminhar de forma libertária rumo a liberdade - também económica (NGOENHA, 2013).

Ora, isso no caso Moçambicano não funcionou como o desejado. Primeiro porque logo depois da independência, a primeira República Moçambicana foi caracterizada adoção oficial da orientação marxista-leninista a partir do III Congresso da Frelimo, em 1977. Época construtora de ideólogos como se verificou no primeiro instituto de Estudos Sociais de Moçambique pós-1975, o Centro de Estudos Africanos, sedeado na Universidade Eduardo Mondlane. Nos últimos anos, houve em Moçambique um diluir de instituições e cursos versados em ciências sociais, mas que de pesquisa e investigação tem muito pouco. Esse fato fez com que o nível de contribuições da parte das ciências sociais moçambicanas caísse por terra.

Para Ngoenha, falta às ciências sociais moçambicanas e de boa parte de África, construir verdades do amanhã, construindo utopias. Nas palavras do mesmo "o que está a faltar, muitas vezes, são verdadeiras utopias e grandes utopias” (NGOENHA, 2013). Ele acrescenta que líderes como Samora Machel e Amílcar Cabral foram 
grandes utopistas. Estes líderes políticos, e outros intelectuais como Cheik Anta Diop, o influenciaram de alguma forma no modo de fazer filosofia.

Se é verdade que os esforços de sublinhar a necessidade de militância utópica através da escrita, da sua parte, tenha começado vigorosamente com a sua obra Por uma Dimensão Moçambicana da Consciência Histórica (1992), Ngoenha foi alimentando este esforço, escrevendo, por exemplo, a Intercultura: alternativa a governação biopolítica (2013), A Terceiro Questão (2015), A (Im)possibilidade do momento moçambicano: notas estéticas (2016), nestas obras, sobretudo na de 2016, Ngoenha crítica a existência em Moçambique de vários debates políticos sem ideias políticas, e por fim, Resistir a Abadon, em 2018, a obra que pode ser considerada a sua mais completa indagação sobre a questão das liberdades. Para ele, no contexto da milenar violência que caracteriza as sociedades, deve-se dissecar o real sentido e a necessidade de construção de utopias que fossem capazes de construir um mundo mais igualitário, mais justo e por isso, defensor do paradigma libertário.

\section{Um Paradigma Libertário}

A ideia de liberdade em Nogenha pode ser entendida - como consta da sua obra Filosofia Africana: das Independências às Liberdade (1993), - como um pensamento associado à condição histórica do africano. Nogenha sustenta que os esforços que começaram na segunda metade do Século XIX, quer eles se chamem pan-africanismo, etnofilosofia, filosofia crítica, negritude ou hermenêutica, se afiguram movimentos que vivem do espírito e tendem para a mesma realidade: a liberdade do africano, condição da sua historicidade (BUANAISSA, 2016).

Desde a obra Por uma Dimensão Moçambicana da Consciência Histórica, Ngoenha defende a necessidade dos moçambicanos adotarem a crítica e a interrogação como forma de interpelação de seu futuro enquanto povos africanos (numa direta interpelação com 
a diversidade de culturas e tradições do continente). Sua filosofia dá importância ao lastro de memória e o significado atribuído ao passado (no período da escravatura, durante o colonialismo e no advento da globalização) com vista a libertar o futuro como verdadeira emancipação, e a partir de escolhas mais consentâneas com a ideia de justiça e de liberdade. Esta utopia de Moçambique (e do mundo) melhor, onde a razão filosófica cristaliza a liberdade, é, sem dúvida, o centro da filosofia de Severino Ngoenha (BUANAISSA, 2016, p. 350). Para Ngoenha, com alguma inspiração sartreana, a liberdade tem que ser o meio e a finalidade da ação humana. Neste sentido, cada cidadão - através da emancipação socioeconómica e política - tem que mobilizar o seu espaço na mesma direção, de modo a inscrever-se na história do seu país e do mundo.

Quaisquer reflexões sobre o histórico da emancipação africana deve articular a busca pela liberdade como emancipação da escravatura e como integração social. Contudo, um século depois do fim da escravização, esta prática desumana ainda continua sob forma de marginalização e estigmatização do povo africano, dos ameríndios e de todos os povos existencialmente fracos, como os líbios e os sírios, só para apresentar dois exemplos (NOGENHA, 2014b, p. 154-156). A estes povos perpetuam-se a pobreza, o subdesenvolvimento, e o mais grave, a violência sob o pretexto de resposta bélica ao terrorismo, por exemplo.

O outro pólo do pensamento severiniano é o da liberdade como emancipação política e como desenvolvimento económico. Se é verdade que nos anos 1960 os povos africanos começaram a alcançar as independências políticas, o mesmo não se pode dizer das liberdades económicas. Praticamente toda a África contínua ainda hoje sob o jugo da pobreza endémica, sob conflitos armados, ditaduras socioeconómicas, assim por diante. Kwame Nkrumah chegou mesmo a defender que o alcance pleno da liberdade política e económica de África só seria possível com a união geral de África (NGOENHA, 2018, p.158-160). Este sonho de união africana geral (não como se apresentou a OUA e muito menos como se tem 
apresentado a UA) acabou sendo ignorado pelas lideranças africanas que viam nela, a redução da preservação dos seus interesses económicos individuais.

\section{Resistir a violência?}

Em Resistir a Abadon, Ngoenha apresenta-nos um conceito de liberdade optimizado relativamente as suas primeiras propostas apresentadas no final do século XX, e mais tarde, no que pode chamar-se de segundo Ngoenha, no primeiro quartel do século XXI. Para ele, nesta nova proposta hermenêutica, a liberdade é vista, num primeiro momento, como distanciamento em relação as modas e correntes da época, e mais ainda, como um sonho de prosperidade e harmonia futura, por isso, como paz e desenvolvimento. Nas suas próprias palavras, "desde sempre, o 'viver juntos', a harmonia, constitui o âmago da reflexão filosófica” (NGOENHA, 2018, p.32).

Na verdade, Ngoenha procura fazer um diagnóstico do que impede o alcance da Eudaimonia (Aristóteles), a busca da felicidade e do bem-estar. Para tal, busca Alexandre Sanguinetti, afirmando que: "a violência é a matriz das sociedades, o pecado original da condição humana” (SANGUINETI apud NGOENHA, 2018, p. 15). Nesse caso, a liberdade seria a condição de distanciar-se dela, da violência. Essa leitura foi mesmo introdutória da sua resistência, e com ela, ele queria apresentar uma reflexão indicativa de que o percurso libertário, poderia ser uma quase "contra-argumentação" ao que essencialmente caracterizou a história da humanidade, a violência, ou como pretendiam referir-se os estóicos, a busca incessante pelos prazeres.

Apesar das diversificadas formas de violência por todo o mundo, Ngoenha define a violência da fome e da indigência que sobrevoa o globo, como a mais incisiva de todas. Na altura em que escrevíamos este texto, podíamos assistir ao jornal da noite de uma estacão de televisão moçambicana, onde se reportava a destruição por parte das autoridades locais - de mais de 20 casas de cidadãos 
pobres, num distrito próximo de Maputo, por alegadamente terem sido construídas em terrenos alheios. Usaram a violência para os amedrontar. Parte dos detentores das casas fizeram empréstimos bancários, e viram tudo a perder. Não se mostrou respeito pela dignidade humana, pelo direito fundamental à habitação. Recentemente, também ouve no mesmo distrito, um caso em que um tribunal decidiu - estranhamente - a favor de uma empresa que se encontrava em disputa de terra com residentes locais. Sobre estes e muitos outros casos que abundam em Moçambique e no mundo, Ngoenha afirma:

'Tout proportion gardée', estamos numa época em que, como diziam os estóicos, 'o pudor, a justiça e a verdade voaram em direç̧ão ao Olimpo, fugindo a guerra que apareceu nos caminhos'. Estas são linhas de Marco Aurélio, das mais pessimistas que a história nos legou. Encontramos sentimentos semelhantes em Séneca e em Epíteto, o que impele muitos historiadores a taxarem os estóicos de pessimistas. No entanto, nestes sábios austeros, temos de ver testemunhas de uma época conturbada e sem referências, como a nossa, contra a qual, a filosofia levanta barreiras (NGOENHA, 2018, p. 16).

Para Ngoenha, a violência privam-nos das liberdades. No Moçambique contemporâneo, isso é uma verdade a la palisse.

A violência se manifesta sob muitas formas, algumas latentes e escondidas, mas nem por isso menos devastantes. É um cancro que se insinua no corpo social e nos atinge lá onde menos esperamos. Foi este o drama do homem Guebuza ${ }^{5}$ que, apesar da sua riqueza e potestade, não conseguiu proteger-se - a si e aos seus - da ira que se tornou estrutural na nossa sociedade, nem sequer dos juízos negativos dos compatriotas, até mesmo nos momentos do seu maior drama familiar. (...) A raiva, a revolta, a frustração e até o ódio que se tinha ao antigo presidente fez com que, mesmo no cemitério, diante da morte, não nascesse um mínimo de simpatia, de compaixão (NGOENHA, 2018, p. 18-19).

${ }^{5}$ Ex-Presidente da República de Moçambique (2004-2014) 
Num outro desenvolvimento, Ngoenha diz que no seu primeiro mandato, Guebuza tentou rebuscar a postura de Samora Machel, mas só nos aspectos excessivos, sem ter nem o seu carisma, nem a sua concepção de posto, e talvez nem sequer os seus valores do período pós-1975, que mobilizavam a ideia da comunidade, da justiça e da solidariedade.

Para Ngoenha, hoje é corriqueiro exaltar o amor profundo pelos direitos humanos, defender a urgência de sair da ditadura, quando simultaneamente se tem um desprezo profundo pelos indivíduos concretos. Enquanto o outro for abstracto, tudo vai bem; mas basta que ele tome uma configuração mais viva, para cair-se na conta de que é difícil viver com ele em carne e osso; então o outro, de repente, aparece menos digno de acolhimento e de solicitude. Torna-se inimigo, obstáculo. A presença física vem anular os melhores élans de altruísmo. Assim, os grandes ideais devem tornar-se álibis para os egoísmos" (Ngoenha, 2018, p.28-29). No fundo, continua Ngoenha, a característica peculiar das reflexões filosóficas dos nossos tempos é ligada a reflexão sobre o outro.

Trata-se de postular que foi a racionalidade governamental que se colocou por detrás dos golpes de Estado e dos assassínios políticos no continente africano. O mesmo espírito que suportou a Mobutu no Congo, o regime de Smith na Ex-Rodésia, o Apartheid na África do Sul e, por consequência, os conflitos armados com a UNITA e a Renamo, em Angola e Moçambique respectivamente. Neste sentido, Ngoenha afirma e questiona:

(...), este tipo de lógica provoca ódio e torna radicais aqueles que viram os seus pais e irmãos morrer sem culpa. Pior, muitas vezes, esses mesmos pais e irmãos sucumbiram outrora à tirania de regimes ditatoriais...Como evitar o círculo vicioso do terror? (NGOENHA, 2018, p. 59)

Para responder a esta questão Ngoenha argumenta que a África, querendo a sua liberdade político-económica, deverá, entre 
outros, libertar-se cientificamente. Sua interrogação é: como fazer isso, quando o essencial das produções científicas africanas depende das metodologias, das epistemologias e dos programas de investigação ocidental? Como libertar a cientificidade africana, quando apesar dos esforços desenvolvidos já há décadas pelo CODERSIA, o espectro das pesquisas africanas não tem nenhuma autonomia, quer de orientação, quer epistémica? Não se trata, para ele, de desvincular-se das regras e padrões da ciência global ou de um isolacionismo da academia africana, trata-se porém, de focalizar os métodos universais aos contextos específicos das comunidades. Não é por acaso que "estudos recentes têm demonstrado a impossibilidade de conceber qualquer global sem uma plataforma subjacente antropológica, social, linguística num lugar concreto, num local” (NGOENHA, 2018, p. 61). E nós acrescentaríamos, numa história particular.

Não se trata das Aventuras da Diferença teorizadas por Vattimo, nem do abdicar do universal, que aliás foi sempre parte das pretensões da filosofia, "a favor de um relativismo cultural, mas de re-mobilizar as linguagens, os saberes e as epistemologias que o universalismo etnocêntrico tinha historicamente descartado" (Idem).

Assim, o desafio actual é redireccionar a tendência da governabilidade ser violenta para as maiorias, e torná-la na exportadora-importadora de benesses, e não dos riscos, como alertou Ulrich Beck. Desta forma, urge agir com criatividade nas produções e invenções locais susceptíveis de impactos globais. Nas suas próprias palavras:

Do ponto de vista epistemológico, trata-se de deixarmos de ser importadores dos discursos, para aprender uma leitura social nossa e autónoma. Isso exige uma avaliação crítica dos pressupostos teóricos a partir dos quais, os nossos discursos - isto é, a nossa ciência - se fundam. Não estou a apostar numa teoria afrocêntrica que se oporia ao eurocentrismo que tem caracterizado todo o período moderno (NGOENHA, 2018, p.62). 
Ngoenha faz uma crítica ao trabalho de peritos internacionais que colaboram com África, impondo modelos políticos e económicos estandardizados, mas que não está a resultar. Para ele, a organização de eleições livres, por exemplo, que se tornaram a face da democracia, não conseguiu desenterrar a estabilidade societária, por ter olhado para a liberdade apenas enquanto capacidade de escolha, mas negligenciado, contra-argumentativamente, aspectos como justiça e equidade.

É sobre a ignorância das questões de equidade e justiça que Ngoenha afirma existirem múltiplas revoltas em todo mundo. Outras revoltas têm sido bastante violentas, chegando mesmo a degenerarse em terrorismo. O interessante em sua abordagem é que "a filosofia não ignora nem desdenha a via da revolta. Contudo, é necessário distinguir a revolta política da revolta filosófica. Na filosofia, a revolta tem uma longa tradição que vai de Diógenes a Sartre. Aliás, pode-se considerar, no essencial, toda a filosofia latino-americana e a filosofia africana como de revolta" (NGOENHA, 2018p. 86).

\section{O percurso - também filosófico - das Revoltas}

Já na antiga Grécia, Diógenes tinha um posicionamento bastante duro e crítico face a injustiça e opressão da época, pois em Atenas, por exemplo, as desigualdades entre ricos e pobres, cidadãos e escravos, entre outros, atingia níveis inimagináveis do viver juntos.

A palavra-chave de Diogenes é 'non serviam'. Não servirei a nada e a ninguém, não me submeterei a nenhum dogma. Este imperativo rebelde antecipa os libertinos negadores de Deus e dos dogmas, os libertários defensores de uma liberdade sem contrição, os revolucionários e os utópicos; os nihilistas detractores do poder dos pais e da autoridade, da tradição e da razão clássica; os ateus, deístas e anunciadores da morte de toda a transcendência, os anarquistas. Contra todos aqueles que serviram outra consciência que não fosse a própria, ele reivindica um homem livre e liberto (NGOENHA, 2018, p.89). 
Aqui, Ngoenha mostra-nos que os Estados, legitimados por poderes constitucionais, tem levado a cabo acções de violência contra os seus cidadãos e, estes consequentemente, se sentem na legitimidade de revoltar-se. Nesse sentido, ele busca Sartre para mostrar que este, não tolerando o colonialismo, os massacres e a opressão, tentou fazer uma filosofia da revolta, que vai desde $O$ Ser e o Nada até ao Temos razão de nos revoltarmos, passando pelo seu teatro. "Esta filosofia encontra uma tradução política no prefácio a 'Aden Arabie' de Paul Nizan e no texto sobre Frantz Fanon (NGOENHA, 2018, p.91).

Mesmo no interior da própria política, Ngoenha afirma que existiram visionários como Amílcar Cabral, que revoltaram-se contra a autoridade dos poderes vigentes. Segundo ele: "Um dos 'terroristas' mais lúcidos, Amílcar Cabral, que aliás privilegiava 'as armas da teoria', dizia que a sua luta (revolta) era 'pela paz, pelo progresso e pela felicidade dos povos'. Quem se poderia opor a um tal programa? Que razões e valores humanos poderiam empurrar homens com tais ambições a se verem obrigados a usar meios de terror para realizar esses ideias?” (NGOENHA, 2018, p.92).

É na linha do acima exposto que Ngoenha afirma que o terrorismo contemporâneo, embora de todos os modos, vil e condenável, tem de ser investigado em todas as suas facetas. Apesar do horror dos meios, talvez não seja inteligente olhá-lo como atrelado a uma qualquer vontade nihilista de destruição; tornou-se a arma dos fracos e desesperados para clamar solidariedade ao seu sofrimento e apelar a compaixão entre os homens, ou se quisermos, ao reconhecimento de uma humanidade comum (Cf. Id. 95).

Apesar de tudo, Ngoenha complementa:

Face aos dramáticos horrores de hoje, torna-se infelizmente difícil descartar a via militar para desarmar terroristas, o que não significa isentar os Estado - democráticos e aliados - das suas culpas e responsabilidades, que, mesmo durante as épocas de paz, fizeram mais mortos do que os terrorristas. Por outro lado, deve- 
se também afirmar veementemente que a guerra é um meio impróprio para fazer face às questões da justiça. Por isso, ela não pode, de nenhuma maneira, ser considerada um bem - um bom caminho - nem a única, nem a última voz. Ela pode parecer neste momento necessária, mas continua sendo um mal (NGOENHA, 2018, p.96).

Lamentavelmente a guerra e a violência têm sempre ganhado na luta com a razão. Na perspectiva material, as infraestruturas do desenvolvimento das sociedades (ruas, pontes romanas, drones, entre outras) são de origem militar. Hodiernamente, a indústria da guerra ocupa um lugar de destaque nas principais económicas do planeta. Já em termos axiológicos, formam-se os jovens, desde a paideia aos marines, no sentido de honra, e esta está ligada, homerianamente, à razão da força, à retaliação, à vingança. E do ponto de vista social, os históricos de guerra abundam os livros, as praças públicas, as artes e os cinemas. No caso moçambicano, só para citar um exemplo, os macondes inscreveram-se neste viés com os trabalhos do artista Gonçalo Mabunda, um dos mais prestigiados artistas moçambicanos, com o qual as armas puderam ser transformadas em obras de arte. O Brasileiro-moçambicano Lícinio de Azevedo, com o seu filme "Comboio de Sal”, também faz parte do mesmo diapasão (NGOENHA, 2018, p.98-99). Uma solução para isso seria a mudança de valores e de prioridades glocais, quer de forma vertical, quer de forma horizontal.

Contudo, a questão permanece: como manter-se focalizado na ideia da liberdade, quando a violência foi ao longo da história o denominador comum das relações sociais? Bem recentemente, "no século XX, ela apresentou-se com as máscaras do nacionalismo, depois, das ideologias, e, hoje, de guerras de religiões; em África, com as máscaras de guerras étnicas ou tribais, civis, religiosas, políticas. As máscaras mudam, mas a única constante é a guerra. Em leituras não difíceis, pode constatar-se que a guerra ganha sempre, criando constantemente novos inimigos, necessidade, 
conflitos, ideologias, oposições, incluindo novos contrários (NGOENHA, 2018, p.100).

No caso Moçambicano, dos ganhos da governabilidade neoliberal, a economia de guerra pode ser confirmada com o cenário das dívidas ocultas ${ }^{6}$, quando por exemplo:

As personagens são: franceses, que rejubilam pelas encomendas das naves; banqueiros e especuladores suíços que emprestam dinheiro para a transacção; armadores holandeses que transportam; libaneses e moçambicanos que adulteram as contas; população moçambicana que tem de pagar as dívidas; militares que usaram as embarcações de guerra; e população que será metralhada por elas. Estas categorias exibem-se piramidalmente, alinhadas de baixo (maior imperfeição) para cima (mais perfeição) (NGOENHA, 2018, p.102).

Com isso, Ngoenha conclui que o mundo da violência se torna o único mundo possível: "Cada um no seu lugar: fabricantescredores-armadores-dinheirocratas-devedores-utilizadoresvítimas. Este não é só o melhor - leibnizianamente falando -, mas também o único mundo possível (NGOENHA, 2018, p.104).

Para explicar sobre o desdobramento da violência como o único mundo possível, Ngoenha reflecte sobre o lugar da guerra nas sociedades, questionando-se sobre como é que a filosofia - que é por essência anti-guerra - pode subsistir diante da universalização e omnipresença da mesma. Como é possível que a paz antecipe as guerras, que a lógica venha antes das ideologias? Que a filosofia tenha primazia sobre as vontades dos fortes? Como resistir a violência?

Ngoenha vê as guerras em Moçambique, que para ele, apesar de mobilizadas internamente, como que motivadas por interesses

\footnotetext{
${ }^{6}$ Moçambique debate-se hoje com a sua pior crise económica desde a adesão a modelo neoliberal de governação, com a queda do muro de Berlim. A crise é devida a contratação de dividas ocultas e ilegais no governo do então Presidente Armando Guebuza, em 2013 e 2014. Com a dívida, o FMI e os parceiros de cooperação internacional suspenderam o seu apoio financeiro ao país, exigindo responsabilização. Até aqui isso não aconteceu, e o país esta a beira de um colapso económico, devido a subida galopante do custo de vida, e a degradação das condições básicas dos sectores sociais.
} 
económicos de grandes actores da geopolítica global. Foi assim nos 16 anos (com a guerra fria), tem sido assim desde o conflito de 2013 com a "redescoberta" do petróleo e gás na bacia do Rovuma, envolvendo multinacionais com expressões globais.

Na ótica Severiniana, o grande receio na prevalência da violência através das guerras, é que fora as mortes e indigência que elas perpetuam, há também um risco profundo delas desgastarem os Estados, afigurando-se instrumentos de desordem contínua, que mina lentamente a nação e, muitas vezes, dividem o país, até geograficamente, como recentemente aconteceu com o Sudão. O curioso, aliás, é que nem o pretexto que as mobiliza - o de alcançar o equilíbrio de forças - é alcançado.

Em Moçambique, o recente conflito armado fez com que recentemente o falecido Dom Jaime Gonçalves, arcebispo católico da cidade da Beira, um dos protagonistas do acordo geral de paz de 1992, clama-se, e Ngoenha o cita: "podemos tocar todos os tambores de uma só vez - ninguém nos vai escutar. Se Moçambique não acabar com a guerra, a guerra vai acabar com Moçambique” (NGOENHA, 2018, p.123). Este grito do arcebispo da Beira foi feito pouco antes da sua morte, e no auge do conflito Frelimo-Governo vs Renamo na actual governação do Presidente Filipe Nyusi. Com quase uma centena de anos, Dom Jaime Gonçalves quis denunciar o paradigma da violência em Moçambique, alertando para a necessidade de desviar-se o curso da história, para um paradigma de paz.

Segundo Ngoenha, a causa do conflito reside no facto que "o indivíduo que emerge depois dos acordos de Roma parecer-se muito com o indivíduo de Stirner. Não se trata de um sujeito emancipado, mas de um indivíduo que usa e abusa das suas relações e pertenças sociais para fins egoístas (NGOENHA, 2018, p.126).

Ora, o tipo e nível de clientelismo que seguiu-se ao 1992 foi deverás desastroso para a economia moçambicana, que fez com que os índices de desigualdades, pobreza endémica e retrocesso económico explodissem exponencialmente. Isso está, de facto, ligado a governabilidade que Ngoenha aborda em sua obra Intercultura: 
alternativa a governação neoliberal? (2014) Para ele, uma forma filosófica de resistir seria revisitar os princípios filosóficos do liberalismo e da democracia, para reformular o projecto político moçambicano, e consequentemente fortificar as instituições. Uma reformulação do imaginário político e meta-institucional moçambicano passaria necessariamente pelo rebuscar da unidade defendida por Kwame Nkrumah em sua obra Africa Must Unite. Contudo:

É essa unidade que não querem os opressores, e por isso, impedem que o movimento cresça. De 1900 a 1919, os conferenciastas tinham decidido reunir-se de dois em dois anos, mas foram impedidos de fazê-lo. Combate-se então a teoria da unidade a favor das teses senghorianas dos espaços coloniais; impede-se por meio das armas a união do Senegal e da Gâmbia; apoia-se com armas também - já então com a cumplicidade de regimes africanos - a tentativa de fragmentação da Nigéria (guerra do Biafra), e, mais tarde do Congo (NGOENHA, 2018, p.131).

A unidade, pelo contrário, iria permitir uma maior coesão na resistência à violência: "um povo reconciliado é menos permeável às solicitações e seduções dos fazedores de conflitos. A estes não os podemos impedir, mas podemos resistir-lhes". É aqui que Ngoenha acrescenta: "neste sentido, o nosso maior problema não são os outros, os que instigam as guerras, mas nós próprios" (NGOENHA, 2018, p.132-133). Isso implica dizer que as nossas paixões individuais, com os seus desdobramentos pelas vontades insaciáveis pelos bens (quase sempre alheios) são o que tem estado na origem e na perpetuação dos conflitos e, por isso, da violência.

\section{Como é possível a Emancipação Económica?}

Em Moçambique, a emancipação política alcançada em 1975 foi possível a partir da fusão de três movimentos nacionalistas (UDENAMO, MANU e UNAMI), bem como a mobilização de diferentes setores da sociedade colonial (com grande variedade 
étnico-tradicional) em busca da Independência. Liderados por Eduardo Mondlane, a primeira fase de formação da FRELIMO (Frente de Libertação de Moçambique) congrega a ambição da partilha de valores que possam integrar cada sujeito histórico nacional (MONDLANE, 1995). Para Ngoenha, "o pressuposto necessário é a crença de que a pertença dos indivíduos à comunidade política e moral é tão importante quanto os seus direitos à liberdade (NGOENHA, 2018, p.139).

Com a luta de Libertação Nacional por via armada, a partir de 1964, a FRELIMO vai sendo construinda no terreno árduo da guerra anticolonial. Neste contexto dispoletaram-se desavenças já mesmo no seio da FRELIMO (NEWITT, 2012), por um lado. Por outro, a própria brutalidade da guerra de libertação (e dos massacres perpetrados pelo exército português, por exemplo) condicionaram, sem dúvida, o movimento a uma visão mais centralista e unitária das próprias energias sociais dispersas. Logo a seguir à Indpendência, em 1975, proclama-se a diretriz do Estado-partido único e, em 1977, formaliza-se a ideologia marxista-leninista como o bordão de construção de um Moçambique uno e indivisível do Rovuma ao Maputo (os rios limítrofes a norte e sul). Neste momento destrava-se uma longa guerra civil que durará até 1992 e irá opor a Frelimo (Estado-partido) e a RENAMO (Resistência Nacional Moçambicana). Deste conflito de dimensões internacionais (pois vincula-se à política da Rodésia/Zimbábue, África do Sul (do Apartheid) e as potências internacionais da Guerra Fria, resultaram, no mínimo 1 milhão de mortes e mais de 5 milhões de deslocações forçadas. Vale dizer que a própria construção do Estado-Nação moderno moçambicano, sua própria cultura organizaciona e institucionalidade, advém deste contexto de grave drama humanitário.

Um dos principais problemas que faz com que Moçambique continue perpetuando o nível de violência - para além do facto de mesma estar associado as ganâncias humanas - está ligado a obediência cega. No olhar de Ngoenha, ela não se restringe 
unicamente aos militares, pois os moçambicanos, ao abdicar de um pensamento autónomo, como ovelhas, seguem religiosamente ao comando do dia. Nesse sentido, qualquer acção fora do "status quo", qualquer acto de pensamento crítico e autónomo é considerado uma heresia e dá direito a "mutilação" (NGOENHA, 2018, p.146).

Ngoenha (2018) diz que os moçambicanos estão sedentos da liberdade, do uso libero da consciência e do pensamento, do uso da palavra e do diálogo, no final, do desenvolvimento íntegro da pessoa, que passa necessariamente pela emancipação económica. Se quiserse essa emancipação, ter-se-ia que percebê-la como a dimensão negativa da não-violência, mas também, do abandono da apatia. Neste sentido, vendo-a também de forma positiva, poderia pensarse na participação activa, viril e determinada da sociedade civil, e dos cidadãos no geral; numa sociedade mais dona da democracia e, por conseguinte, do seu destino.

Quanto a participação da Sociedade Civil e de outras forças vivas da sociedade, Ngoenha crítica a ausência de espaços partilhados em Moçambique. Os partidos políticos são completamente excluídos do actual processo de paz e de perspectivas económicas. O Movimento Democrático de Moçambique (MDM), mesmo com acento parlamentar, só é informado sobre os avanços das negociações de Paz. Nisso tudo, a sociedade civil é a mais ignorada. Ela, apesar da sua proximidade na defesa dos interesses dos cidadãos, tem reclamado disso várias vezes, mas sem espaço de auscultação. É preciso alcançar a liberdade política - no sentido mais abrangente do termo - não só para as elites da Frelimo e da RENAMO, mas também de outras forças político-partidárias, e sobretudo, dos cidadãos, que no caso moçambicano, tem a sociedade civil como a sua mais forte face de expressão. Isso iria permitira alargar os espaços de projecção de harmonia e de desenvolvimento do país, e no final, possibilitaria a liberdade também económica.

\section{Notas finais}


Do que atrás ficou exposto, fica a evidência da necessária defesa e ampliação das liberdades no contexto moçambicano e da inadiável reconciliação nacional em torno de uma cultura avessa ao exercício sistemático da violência. Neste país africano, a filosofia de Severino Ngoenha tem um papel fundamental em busca deste alvitre. Para ele, infelizmente, são as vontades particulares que continuam a fazer emperrar a paz e consequentemente alimentar os conflitos e as guerras.

A filosofia e o filósofo revoltam-se contra a desordem do país e do
mundo, conta as opressões, as desigualdades, as injustiças, a
violência. Ao mesmo tempo, militam pela contrição de uma família
fundada sobre a justiça, e por isso, sobre a liberdade. Esse é o lugar
e o tempo para sonharmos novas utopias: prover alimentos para
todos, democratizar a democracia, criar uma sociedade mais
transparente e participativa, tornar os partidos verdadeiros
preceptores de projectos nacionais, abandonar a guerra como
caminho da Eudaimonia e bem-estar particular, e abraçar o
diálogo (NGOENHA, 2018, p.155).

Ngoenha (2014) indica que dos muitos caminhos possíveis para o alcance dessa liberdade, um dos mais credíveis seria o cultivo real do espírito de solidariedade entre as gentes e povos, já não unicamente na relação Norte-Sul, mas acima de tudo, no interior das próprias culturas, em que as populações poderiam ser galvanizadas pela partilha de bens, e por isso, pela intercultura. Associado a isso, é importante que a as ciências sociais e humanas, nos exemplos da filosofia e da história, das sociologias e das antropologias, das linguísticas e dos estudos da religião, bem como das ciências educacionais, e outras afins, se dediquem com afinco, na nova "luta" pela segunda vaga da libertação política, o que iria reduzir os índices de violência nas suas múltiplas dimensões, mas sobretudo, iria possibilitar o grande sonho de uma liberdade económica, e por isso, de um mundo mais justo e distributivo. 
É verdade que os apetites dos arquitectos da biopolítica (para falar como Foucault) ou da governabilidade neoliberal, mascarados em multinacionais e grandes instituições financeiras, mas também em príncipes-cordeiros no interior das fronteiras, dificilmente irão parar. A medida que as ciências humanas forem encontrando novas propostas alternativas para o alcance das liberdades, os grandes peritos do neoliberalismo poderão estar um passo enfrente, na corrida desenfreada pelos recursos em detrimento de milhões de almas. Mesmo assim, na óptica de Ngoenha, uma saída seria possível: seria necessário que os povos subjugados estabelecessem parâmetros justos de desenvolvimento, e que a distribuição equitativa das riquezas se tornasse um imperativo categórico nacional. Se para tal fosse necessário subverter a ordem da autoridade do dia pelo bem maior, por intermédio do diálogo e da resistência inteligente (não violenta), que assim o fosse. $\mathrm{O}$ importante é de facto, engajar-se por um mundo melhor, um mundo mais justo. É caminhar para a liberdade, isto é: a Paz, o Desenvolvimento e a Felicidade dos Povos.

\section{Referências}

BUANAISSA, Eduardo. "O paradigma libertário de Severino Ngoenha: uma encruzilhada subversiva”. In: MACEDO, José Rivair (Org.). O Pensamento Africano no século XX. São Paulo: Outras Expressões, 2016.

MONDLANE, Eduardo. Lutar por Moçambique. Maputo: Nosso Chão, 1995.

NEWITT, Maylin. História de Moçambique. Lisboa: Europa-América, 2012.

NGOENHA, S. "Emancipação" In: SANSONE, L. \& FURTADO, C. (Orgs). Dicionário crítico das ciências sociais dos países de fala portuguesa, Bahia, ABA Publicações, 2014.

NGOENHA, S. A (Im)possibilidade do Momento Moçambicano: notas estéticas. Maputo: Alcance Editores, 2016. 
26 | Revista Opinião Filosófica, Porto Alegre, V. o9; No. 01, 2018

NGOENHA, S. Estatuto e axiologia da educação. O paradigmático questionário da missão suíça. Maputo: Livraria Universitária, 2000.

NGOENHA, S. Filosofia Africana. Das independências as liberdades. Porto: Edições Paulinas, 1993.

NGOENHA, S. Intercultura, Alternativa a Governação Neoliberal? Maputo: Publifix, 2014.

NGOENHA, S. Os tempos da filosofia. Filosofia e democracia em Moçambique. Maputo: Imprensa Universitária, 2004.

NGOENHA, S. Por uma dimensão moçambicana da consciência histórica. Porto: Salesianas, 1991.

NGOENHA, S. Resistir a Abadon. Maputo: Paulinas, 2018.

NGOENHA, S. Severino Elias Ngoenha (depoimento, 2011). Rio de Janeiro, CPDOC/FGV; LAU/IFCS/UFRJ; ISCTE/IUL; IIAM, 2013, 47 pp.

NGOENHA, S. Terceira Questão: que leitura se pode fazer das recentes eleições presidenciais e legislativas? Maputo: Publifix, 2015.

NGOENHA, S. Vico e Voltaire. Duas interpretações filosóficas do século XVII. Porto: Edições Salesianas, 1992.

PAREDES, Marçal de Menezes. “A construção da identidade nacional moçambicana no pós-independência: sua complexidade e alguns problemas de pesquisa. Anos 9o, Porto Alegre, v. 21, n. 40, p. 131-161, dez. 2014. 